\title{
Pengaruh Penambahan Giberelin Terhadap Pertumbuhan dan Persentase Batang dan Akar Tanaman Jagung Dengan Sistem Hidroponik
}

\author{
The Effect Gibberellin Addition on Growth and Percentage of Stems and Roots of Corn Plants with a Hydroponic \\ System
}

Leni Mulyani1 ${ }^{*}$, Lizah Khairani², lin Susilawati²

${ }^{1}$ Program Studi Peternakan, Fakultas Peternakan, Universitas Padjadjaran, PSDKU Pangandaran, Indonesia 2Fakultas Peternakan Universitas Padjadjaran, Jalan Raya Bandung-Sumedang KM 21 Sumedang 45363

\begin{abstract}
Abstrak
Penelitian ini bertujuan untuk mengetahui pengaruh penambahan giberelin terhadap pertumbuhan dan persentase batang dan akar tanaman jagung dengan sistem hidroponik. Penelitian ini dilaksanakan di Laboratorium Fakultas Peternakan PSDKU Universitas Padjadjaran Pangandaran, pada bulan Desember 2019 - Januari 2020. Metode yang digunakan dalam penelitian ini adalah eksperimental dengan Rancangan Acak Lengkap (RAL) dengan 4 perlakuan dan 5 kali ulangan. Perlakuan berupa P0 (kontrol), P1 (penambahan 5 ppm giberelin), P2 (penambahan 10 ppm giberelin), P3 (penambahan 15 ppm giberelin). Peubah yang diamati adalah pertumbuhan tanaman jagung secara hidroponik yang meliputi tinggi tanaman dan persentase batang dan akar yang meliputi berat kering batang dan berat kering akar. Data diuji dengan menggunakan analisis ragam dan untuk mengetahui perbedaan antar perlakuan dilakukan uji jarak berganda Duncan. Hasil penelitian terhadap pertumbuhan tanaman jagung dan persentase batang dan akar tanaman jagung. Rata-rata tinggi tanaman jagung selama 13 hari penanaman dengan sistem hidroponik menunjukkan kisaran pada 19,62 - 23,66 cm serta rata-rata persentase batang tanaman jagung menunjukkan kisaran pada 36,56 - 40,95 persen, sedangkan rata- rata persentase akar tanaman jagung menunjukkan kisaran pada 59,05 - 63,44 persen.
\end{abstract}

Kata Kunci: Jagung, hidroponik, pertumbuhan, persentase batang dan akar

\section{Abstract}

The aim of this study was to determine the effect of the addition of gibberellin on the growth and percentage of corn stems and roots with a hydroponic system. The research was conducted at the Laboratory of Faculty of Animal Husbandry PSDKU Universitas Padjadjaran Pangandaran, in December 2019 - January 2020. This research was design with an experimental method using Completely Randomized Design (RAL) with 4 replication and 5 experimental units. The treatments examined were the gibberellins addition, they are P0 (control), P1 (addition of 5 ppm gibberellins), P2 (addition of 15 ppm gibberellins), and P3 (addition of 15 ppm gibberellins). Variables observed were plant height and the percentages of stems and roots like the dry weight of the stems and the roots. The data were analysed by using Variance Analysis and the treatment difference was examined by using Duncan's Multiple Range Test. The result showed the treatment of addition of gibberellins did not affect the growth and percentage of stems and roots' corn. The height of corn plants for 13 days of planting with the hydroponic system showed a range of $15.0-32.0 \mathrm{~cm}$ and the percentage of corn stems showed a range of 28.0 - 54.0 percent, while the percentage of corn plant root showed a range of $42.0-$ 72.0 percent.

Keywords: corn, hydroponic, growth, percentage of stems and roots

\section{PENDAHULUAN}

Salah satu faktor penting untuk menunjang keberhasilan usaha peternakan adalah pakan. Hijauan merupakan sumber pakan utama yang biasa diberikan kepada ruminansia. Maka ketersediaan hijauan perlu diperhatikan. Terjadinya alih fungsi lahan menjadi salah satu faktor penghambat ketersediaan hijauan. Waktu tumbuh yang relatif lama juga menjadi kendala dalam penyediaan hijauan secara berkelanjutan.

Solusi memproduksi hijauan pakan yang dapat dilakukan yaitu dengan cara hydroponik fodder. Teknik hidroponik ini tidak memerlukan lahan yang luas karena dapat disimpan dirak secara bertingkat. Keuntungan dari hydroponik fodder yaitu hijauan yang dihasilkan dapat dimakan semuanya mulai dari akar, batang sampai daun. Adapun keuntungan lainnya dapat meminimalisir adanya hama, kebersihan dapat lebih terjaga serta pemantauan dapat dilakukan dengan lebih mudah.

Jagung merupakan salah satu tanaman pakan yang produksinya singkat untuk mendapatkan hijauan pakan. Berat rata-rata biji jagung 250-300 mg. Dari 1 kilogram benih yang dibuat hydroponik fodder dapat menghasilkan 5-6 kilogram hijauan segar dengan kandungan berat kering sekitar 11-14\% (Naik dan Singh, 2013). 
Faktor yang mempengaruhi keberhasilan hidroponik yaitu zat pengatur tumbuh. Zat pengatur tumbuh merupakan senyawa bukan nutrisi yang dapat mendorong, menghambat atau secara kualitatif mengubah pertumbuhan dan perkembangan tanaman. Salah satu zat pengatur tumbuh adalah giberelin. Pemberian giberelin terhadap tanaman mampu meningkatkan pembelahan sel serta pembesaran sel. Giberelin juga dapat merangsang perkecambahan benih serta bersifat mengendalikan pertumbuhan aktif tanaman (Tanimoto, 2005).

Pemberian konsentrasi giberelin yang tepat pada masa pertumbuhan dapat memacu pertumbuhan tanaman melalui peningkatan tinggi tanaman dan luas daun. Tinggi tanaman jagung yang ditanam dengan sistem hidroponik akan menghasilkan tinggi 20-30 cm (Naik et.al., 2015).

Salah satu cara perlakuan menggunakan zat pengatur tumbuh adalah dengan cara priming. Priming merupakan perlakuan perendaman benih dalam larutan yang mengandung suatu zat pengatur tumbuh. Keunggulan dari priming yaitu dapat memperbaiki pertumbuhan awal tanaman serta mempercepat tumbuhnya kecambah (Murungu dkk, 2004). Priming juga dapat meningkatkan persentase perkecambahan (Ilyas, 1995). Tujuan dari penelitian ini adalah untuk mengetahui pengaruh penambahan giberelin terhadap pertumbuhan tanaman jagung, yang direfleksikan melalui karakteristik pertumbuhan tanaman, yaitu tinggi tanaman, proporsi batang, dan proporsi akar tanaman jagung.

\section{METODOLOGI}

Penelitian dilakukan di Laboratorium Fakultas Peternakan PSDKU Universitas Padjadjaran Pangandaran, pada bulan Desember 2019 - Januari 2020. Penelitian ini dilakukan dengan prinsip pemberian perlakuan seperti yang telah dijelaskan oleh Asra (2014). Penelitian menggunakan metode eksperimental dengan rancangan percobaan Rancangan Acak Lengkap (RAL) dengan 4 perlakuan yaitu: $\mathrm{P} 0=$ kontrol, $\mathrm{P} 1=$ penambahan 5 ppm giberelin, $\mathrm{P} 2$ $=$ penambahan $10 \mathrm{ppm}$ giberelin, $\mathrm{P} 3=$ penambahan 15 ppm giberelin. Data penelitian diolah menggunakan program excel.

\section{Seleksi Benih Jagung}

Benih direndam di dalam air untuk mengetahui benih yang baik dan tidak baik. Benih yang tidak mengambang direndam di dalam larutan fungisida selama 15 menit kemudian ditiriskan. Kemudian benih direndam kembali dengan air yang sudah ditambahkan dengan giberelin dengan masing-masing dosis yaitu 0 ppm, 5 ppm, 10 ppm dan 15 ppm selama 5 jam.

Benih jagung yang sudah melalui tahap seleksi dan perendaman kemudian disebar pada nampan yang telah diberi label sesuai dengan perlakuan, yaitu $\mathrm{P} 0=$ kontrol (benih jagung yang ditanam secara hidroponik tanpa penambahan giberelin dalam proses perendaman), $\mathrm{P} 1=$ benih jagung yang ditanam secara hidroponik

dengan penambahan giberelin sebanyak $5 \mathrm{ppm}$ dalam proses perendaman, $\mathrm{P} 2=$ benih jagung yang ditanam secara hidroponik dengan penambahan giberelin sebanyak $10 \mathrm{ppm}$ dalam proses perendaman, $\mathrm{P} 3=$ benih jagung yang ditanam secara hidroponik dengan penambahan giberelin sebanyak $15 \mathrm{ppm}$ dalam proses perendaman, kemudian disusun di dalam rak bertingkat. Tray ditutup menggunakan trashbag hitam untuk merangsang pertumbuhan selama tiga hari.

Selama benih belum berkecambah, penyemprotan dilakukan dengan air setiap 2-3 jam untuk menjaga benih agar tetap lembap. Setelah benih berkecambah, penyemprotan dilakukan dengan penambahan larutan nutrisi AB Mix sampai panen tiba.

\section{Peubah yang Diamati}

Peubah yang diamati dalam penelitian yaitu perubahan pertumbuhan tanaman jagung yang meliputi tinggi tanaman serta persentase batang dan akar tanaman jagung. Pemeliharaan pertumbuhan dilakukan selama 13 hari penanaman setelah benih direndam oleh giberelin.

\section{HASIL DAN PEMBAHASAN}

\section{Penambahan Giberelin Terhadap Tinggi Tanaman Jagung}

Tinggi tanaman merupakan ukuran tanaman yang paling mudah dilihat. Pengukuran tinggi tanaman dilakukan dengan cara mengukur tanaman dalam keadaan normal dari ujung daun sampai titik ujung akar tertinggi. Tinggi tanaman berkaitan dengan penambahan jumlah dan ukuran sel (Zulfitri, 2015).

Berdasarkan hasil penelitian mengenai pengaruh penambahan giberelin terhadap tinggi tanaman jagung secara hidroponik diperoleh hasil seperti yang ditampilkan pada tabel 1. Berdasarkan tabel 1, rata-rata pertumbuhan tinggi tanaman jagung selama 13 hari penanaman menunjukkan kisaran pada 19,62 - 23,66 cm. Hal ini sesuai dengan pendapat Naik et.al., 2015 yang menyatakan bahwa tinggi tanaman jagung yang ditanam dengan sistem hidroponik akan menghasilkan tinggi 20$30 \mathrm{~cm}$.

Hasil analisis ragam menunjukkan bahwa penambahan giberelin terhadap tinggi tanaman jagung tidak meberikan pengaruh yang nyata $(\mathrm{P}>0,05)$. Hal ini disebabkan karena giberelin hanyalah hormon tumbuh yang berperan penting dalam proses perkecambahan (Bey, dkk., 2005).

Hal ini sejalan dengan pendapat Sutejoe dan Karta Sapoetra (1988) yang menyatakan bahwa pertumbuhan tanaman saling berkaitan dengan faktor yang lainnya, tidak hanya dipengaruhi oleh faktor hormon dan nutrisi saja.

\section{Penambahan Giberelin Terhadap Persentase Batang dan Akar Tanaman Jagung}

Kemampuan suatu tanaman dalam menyerap unsur hara dapat menunjukkan persentase batang dan akar tanaman yang dapat dilihat dari berat kering tanaman. Menurut Ekowati dan Nasir (2011) untuk mengetahui potensial dari tanaman dapat dilihat dari berat kering karena tidak dipengaruhi oleh status air suatu tumbuhan. 
Berdasarkan hasil penelitian mengenai pengaruh penambahan giberelin terhadap persentase batang dan akar tanaman jagung secara hidroponik diperoleh hasil seperti yang ditampilkan pada tabel 1 .

Berdasarkan tabel 1 rata- rata persentase batang tanaman jagung menunjukkan kisaran pada 36,56 - 40,95 persen. Persentase akar tanaman jagung menunjukkan kisaran pada 59,05 - 63,44 persen (Tabel 1). Persentase batang dan akar tanaman jagung ini menunjukkan bahwa persentase akar tanaman jagung lebih besar dibandingkan dengan batang.

Hasil analisis ragam menunjukkan bahwa penambahan giberelin terhadap tinggi tanaman jagung tidak memberikan pengaruh yang nyata $(\mathrm{P}>0,05)$. Hal ini sesuai dengan pendapat Afzal dkk (2002) menyatakan bahwa tingginya laju pembelahan sel pada akar dengan metode priming pada benih menyebabkan lebih tingginya penyerapan air dan nutrisi serta menghasilkan pertumbuhan dan perkembangan akar yang lebih tinggi.

Tabel 1. Pengaruh penambahan giberelin terhadap tinggi tanaman, proporsi batang, dan proporsi akar tanaman jagung.

\begin{tabular}{|c|c|c|c|c|c|c|}
\hline \multirow{2}{*}{ Item Parameter } & \multicolumn{4}{|c|}{ Perlakuan } & \multirow{2}{*}{ p-value } & \multirow{2}{*}{ Keterangan } \\
\hline & PO & P1 & P2 & P3 & & \\
\hline Tinggi Tanaman (cm) & 19,62 & 19,62 & 23,16 & 23,66 & $>0,05$ & Tidak Berbeda nyata \\
\hline Proporsi batang (\%) & 36,56 & 40,95 & 40,88 & 40,28 & $>0,05$ & Tidak Berbeda nyata \\
\hline Proporsi akar (\%) & 63,44 & 59,05 & 59,12 & 59,72 & $>0,05$ & Tidak Berbeda nyata \\
\hline
\end{tabular}

\section{KESIMPULAN}

Pengaruh penambahan giberelin terhadap pertumbuhan dan persentase batang dan akar tanaman jagung dengan sistem hidroponik memberikan pengaruh yang sama atau tidak ada pengaruh terhadap pertumbuhan (tinggi tanaman jagung) serta terhadap persentase batang dan akar tanaman jagung (berat kering batang dan berat kering akar). Perlu dilakukan penelitian lebih lanjut mengenai pengaruh pemberian zat pengatur tumbuh dengan dosis dan cara yang berbeda pada tanaman jagung secara hidroponik guna menambah informasi lebih lanjut mengenai pengarug penambahan giberelin terhadap pertumbuhan dan persentase batang dan akar tanaman jagung dengan sistem hidroponik.

\section{DAFTAR PUSTAKA}

Afzal, I., S. M. A. Basra, N. Ahmad, M. A. Cheema, E. A. Warraich, and A. Khaliq. 2002. Effect of priming and growth regulator treatments on emergence and seedling growth of hybrid maize (Zea mays L.). Int. J. Agric. Biol 4:303-306.

Asra, R. 2014. Pengaruh hormon giberelin (GA3) terhadap daya kecambah dan vigoritas Calopogonium caeruleum. Biospecies 7:29-33.

Bey, Y., W, S., \& N, N. 2005. Pengaruh Pemberian Giberelin pada Media Vacint dan Went terhadap Perkecambahan Biji Anggrek Bulan (Phlaenopsisamabilis. BL) Secara In- vitro. Jurnal Biogenesis, 1(2), 57-61.
Ekowati, D., \& Nasir, M. 2011. Pertumbuhan Tanaman Jagung (Zea Mays L.) Varietas Bisi- 2 Pada Pasir Reject dan Pasir Asli di Pantai Trisik Kulonprogo. Jurnal Manusia dan Lingkungan, 18(3), 220-231.

llyas, S. 1995. Perubahan fisiologis dan biokimia dalam proses seed conditioning. Kel. Benih 6:70-79.

Murungu, F. S., Chiduza, C., Nyamugafata, P., Clark, L. J., Walley., W. R., and Savage,

Naik PK dan Singh NP. 2013. Hidroponics Fodder Production: An Alternative Technology for Sustainable Livestock Production Against Impeding Climate Change. Model Training Course on Management Strategies for Sustainable Livestock Production Against Impeding Climate Change. Pp. 70-75. 18-23 November 2013. Southern Regional Station, National Dairy Research Institute, Adugodi, Bengaluru, India.

Naik PK, Swain BK, and Singh NP. 2015. Hydroponics: its feasibility as an alternative to cultivated forages. In Eco-Responsive Feeding and Nutrition: Linking Livestock and Livelihood.

Sutedjo, \& Karta, S. 1988. Fisiologi Tanaman 1. Jakarta: Bumi Aksara.

Tanimoto, E. 2005. Regulation of Root Growth by Plant Hormones-Roles for Auxin and Gibberellin. CRC. Crit. Rev. Plant Sci. 24:249-265 Available at https://doi.org/10.1080/07352680500196108.

Zulfitri, I. 2015. Analisis Varietas dan Polibag terhadap Pertumbuhan serta Hasil Cabai (Capsicum annum L.) Sistem Hidroponik. Skripsi. Fakultas Pertanian Institut Pertanian Bogor. 